\title{
Waterborne 17 $\alpha$-Ethynylestradiol Affects Aggressive Behaviour of Male Fathead Minnows (Pimephales promelas) under Artificial Spawning Conditions
}

\author{
Andrew R. Majewski, ${ }^{1 *}$ Paul J. Blanchfield ${ }^{2}$ Vince P. Palace $^{1,2}$ \\ AND KERRY WAUTIER ${ }^{2}$ \\ ${ }^{1}$ Department of Zoology, Z230 Duff Roblin Building, University of Manitoba, Winnipeg, \\ ${ }^{2}$ Fisheries and Oceans Canada, Freshwater Institute, Winnipeg, Manitoba R3T 2N6
} Manitoba R3T 2N2

\begin{abstract}
Among fishes, courtship behaviour and nesting defense are strong predictors of reproductive success. We conducted three experiments to assess the impacts of exposure to $17 \alpha$-ethynylestradiol (EE2) on the ability of male fathead minnows (Pimephales promelas) to establish and defend a spawning territory. Fish were exposed to EE2 ( 2 or $8 \mathrm{ng} \mathrm{L}^{-1}$ ) for 27 days, while spawning conditions were gradually optimized. Control (ethanol only) males (C) were paired with treated males ( $\mathrm{L}=$ low dose, $\mathrm{H}=$ high dose) (experiment 1 ) or individuals from their own treatment group (experiment 2) in competition for a nest site. Solitary males occupied a nest site prior to adding a second male from the same treatment group in experiment 3 . Behaviour was quantified from video records. Exposure to EE2 impaired a male's ability to compete and acquire territories compared to unexposed individuals (experiment 1), but was similar when males were paired with like-treated conspecifics (experiments 2 and 3). Higher levels of overall aggression (aggression rates of both fish) occurred in Cvs.L and Cvs.H than Cvs.C trials (experiment 1). Induction of vitellogenin was significantly higher in exposed fish relative to controls.
\end{abstract}

Key words: $17 \alpha$-ethynylestradiol, fathead minnow, behaviour, spawning, nest site

\section{Introduction}

Sewage treatment plants release a complex mixture of natural and synthetic chemicals into the aquatic environment, many of which are partially or completely resistant to biodegradation during treatment (Desbrow et al. 1998; Ternes et al. 1999). As a result, many surface waters, including drinking water supplies, contain sufficient concentrations of natural and synthetic xenoestrogens to cause reproductive abnormalities in oviparous vertebrates, birds, reptiles and fish (Folmar et al. 2000).

$17 \alpha$-Ethynylestradiol is the most common estrogenic compound used in oral contraceptives. It is excreted in human urine, and various studies have shown EE2 concentrations in sewage treatment plant effluent ranging from below the detection limit of approximately $0.5 \mathrm{ng} \mathrm{L}^{-1}$ to

*Corresponding author; majewskia@dfo-mpo.gc.ca 
$7.0 \pm 3.7 \mathrm{ng} \mathrm{L}^{-1}$ (Harries et al. 1996; Desbrow et al. 1998; Larsson et al. 1999; Kuch and Ballschmiter 2000). The low solubility of EE2 is believed to contribute to its increased resistance to biodegradation relative to natural steroidal estrogens (Desbrow et al. 1998). EE2 is an extremely potent synthetic estrogen, and is capable of producing physiological effects in fish at concentrations as low as $0.3 \mathrm{ng} \mathrm{L}^{-1}$ (Harries et al. 1996). Exposure to endocrine-disrupting hormones may lead to decreased fertility and egg production in female fish (Kramer et al. 1998; Zillioux et al. 2001), and reduced gonad size or feminization in males (Rodgers-Gray et al. 2000). Developmental and reproductive impairment has been shown to occur at any life history stage (Arcand-Hoy and Benson 1998).

For most animals, the ability to perform appropriate sexual behaviours is critical to reproductive success (Bayley et al. 1999). The hormonal pathways and associated mechanisms of hormonal control of sexual behaviour in fish are not well understood, but it is clear that sex steroids play a key role (Demski and Hornby 1982; Kyle and Peter 1982; Borg 1994; Arcand-Hoy and Benson 1998; Bayley et al. 1999). Reproductive behaviours associated with mating and spawning serve to bring together sexually compatible mates and, for most fish species, result in the simultaneous release of gametes (Bjerselius et al. 2001). Therefore, impairment of the ability to perform appropriate reproductive behaviours may significantly impact measures of fitness since success in attaining suitable mates and fertilization of gametes may be substantially lowered.

The reproductive behaviour of the male fathead minnow (Pimephales promelas) has been well documented (Wynne-Edwards 1932; Richardson 1937; McMillan and Smith 1974; Cole and Smith 1987). Agonistic interactions between breeding fathead males have been closely linked with the establishment and defense of territories (McMillan and Smith 1974). During the spawning season, male fathead minnows establish nest sites on the underside of submerged or floating objects where they spawn and guard eggs for three to five weeks (Unger 1983). Male fathead minnows defend their nest site from conspecific males as well as from interspecific and intraspecific egg predators. Thus, the ability of male fathead minnows to establish and defend a territory is a strong determinant of reproductive success for this species (Unger 1983).

Exposure of fathead minnows to EE2 has resulted in impaired development of secondary sexual characteristics, histological damage of the gonads (Miles-Richardson et al. 1999), inhibition of egg production (Kramer et al. 1998), and the induction of vitellogenin (VTG) synthesis (Kramer et al. 1998; Nichols et al. 1999; Korte et al. 2000; Panter et al. 2000). VTG is an estrogen-dependent glycoprotein that is synthesized by the liver of female oviparous vertebrates and normally increases in concentration during oocyte development (Allen et al. 1999; Solé et al. 2000). Male fish also possess the VTG gene, but it is normally latent. Exposure to various concentrations of estrogenic compounds has shown dose-dependent induction of VTG in male fish (Sumpter 1995; Miles-Richardson et al. 1999). Production of VTG in fish has been widely used as a biomarker for estrogenic activity 
in sewage effluent (e.g., Harries et al. 1996, 1997, 1999; Larsson et al. 1999). There have been no attempts to examine effects of estrogenic contaminants on behavioural endpoints for this species. Here we present data on the ability of male fathead minnows to establish and defend territories after exposure to environmentally relevant concentrations of waterborne EE2 (2 and $8 \mathrm{ng} \mathrm{L}^{-1}$ ) and examine the relationship of plasma VTG concentrations with our behavioural estimates of reproductive success.

\section{Methods and Materials}

\section{Animals}

Fathead minnows were obtained from the Experimental Lakes Area in northwestern Ontario $\left(49^{\circ} 31^{\prime} \mathrm{N}\right.$; $\left.93^{\circ} 50^{\prime} \mathrm{W}\right)$ and transported in plastic bags containing lake water with oxygen in the headspace until they reached the holding facility at the Freshwater Institute, Winnipeg, Man. $(<24 \mathrm{~h})$. A sample of 20 fish was anesthetized in tricaine methanesulfonate (MS-222), blotted dry, weighed $(0.1 \mathrm{~g})$ and measured for fork length $(\mathrm{mm})$. Four hundred and fifty minnows were divided equally among three 160-L fiberglass tanks receiving $250 \mathrm{~mL} \mathrm{~min}^{-1}$ of dechlorinated Winnipeg city tap water. Fish were fed TetraMin ${ }^{\circledR}$ flake food twice daily at a ration of $2 \%$ of body weight.

\section{Dosing and Exposure Conditions}

Two separate stock solutions were made by dissolving $100 \mathrm{mg}$ of EE2 (Sigma Chem. Co., St. Louis, Mo.) in $2 \mathrm{~mL}$ of warmed ethanol $\left(40^{\circ} \mathrm{C}\right)$, and then diluting an appropriate amount of this stock solution into $2 \mathrm{~L}$ of absolute ethanol in a glass container. After thorough mixing of the ethanol suspension, $18 \mathrm{~L}$ of distilled de-ionized water (DDW) was added for a final pumping solution volume of $20 \mathrm{~L}$. A solvent control solution was prepared consisting of $2 \mathrm{~L}$ of ethanol and $18 \mathrm{~L}$ of DDW. All solutions were maintained at room temperature.

Following a 27-d acclimation period, peristalic pumps were simultaneously started to deliver $0.25 \mathrm{~mL} \mathrm{~min}^{-1}$ of stock solution into each tank to maintain nominal EE2 concentrations of 2 or $8 \mathrm{ng} \mathrm{L}^{-1}$ continuously for $27 \mathrm{~d}$. During the acclimation period, and the first 16 days of exposure, temperature in the tanks was maintained at $11.0^{\circ} \mathrm{C}$ and photoperiod was maintained at 12:12 h light:dark using Vita-Lite ${ }^{\circledR}$ full-spectrum flourescent lamps. After this point, temperature in the tanks was raised to 24.0 to $25.0^{\circ} \mathrm{C}$ and photoperiod was altered to $16: 8 \mathrm{~h}$ light:dark in equal increments over four days. Water and stock solution flow rates were checked twice daily to assure consistent concentrations of EE2 in the tanks. The actual concentration of EE2 in each tank was determined using a radioimmunoassay at $12 \mathrm{~d}$ into the exposure period (see Palace et al. 2001). After completion of the exposure period, leftover stock solution from each treatment was analyzed for EE2 concentrations using standard radioimmunoassay techniques. 


\section{Video Observations}

All experiments were conducted in a $30-\mathrm{L}(30 \times 32 \times 32 \mathrm{~cm})$ glass aquarium containing a nest site, and recorded by video camera (Sony ${ }^{\circledR}$ Hi-8) from behind a blind approximately $0.6 \mathrm{~m}$ away. The nest site was a $10.0-\mathrm{cm}$ long piece of PVC pipe (10.5 cm diameter) cut lengthwise to make a semi-circular shelter. The temperature of the observation aquarium was maintained at $23.5^{\circ} \mathrm{C}$. Sexually mature males were chosen based on the presence of secondary sexual characteristics such as tubercles, banding and spotting, and the presence of a dorsal mucous pad. Prior to observations, fish were weighed to $0.01 \mathrm{~g}$.

In experiment 1, males from each of the two EE2 treatment groups were paired with males from the control group to examine the relative ability of treated males to compete for a nest site. Fish in an individual pair were added simultaneously to the observation tank and the behaviour of both individuals was recorded for $10 \mathrm{~min}(\mathrm{n}=9$ trials). In the second experiment, males from each of the two EE2 treated tanks were paired with males from the same treatment group to examine differences in overall aggression amongst treatment groups. Pairs of fish were added simultaneously to the observation tank and behaviour was recorded for $10 \mathrm{~min}$ ( $\mathrm{n}=5$ trials). In the third experiment, males from each treatment were individually added to the observation tank and allowed $40 \mathrm{~min}$ to establish a territory beneath the nest site (i.e., nest site acquisition). This experiment served to examine differences in the frequency of nest site acquisition and latency to nesting amongst treatment groups. Latency to nesting is defined as the amount of time between the introduction of a fathead minnow to the observation tank and the onset of nest site acquisition (Table 1). If a male did not establish a territory (i.e., begin "nesting" behaviour, see Table 1) within $40 \mathrm{~min}$, that male was replaced with another male. A second male from the same treatment was added to the tank five min after the initial male established ownership of the nest site. Behaviour was recorded for 10 min upon introduction of the second male (Cvs.C: $\mathrm{n}=5$ trials, Lvs.L: $\mathrm{n}=4$ trials, Hvs.H: $\mathrm{n}=5$ trials). Pairs from the ethanol group served as controls for each of the experiments. All behavioural observations were conducted during a 4-d period, between 07:30 and 19:30, beginning immediately after the exposure period. In each experiment, trials were alternated between treatment pairs in order to account for possible changes in behavioural responses over time due to excretion of EE2 by the minnows.

Video records of male fathead behaviour were analyzed using The Observer $^{\circledR}$ (version 3.0; Noldus Information Technology, Wageningen, The Netherlands). The frequency of "contact aggression" and "non-contact aggression" behaviours (Table 1) was too low for statistical comparison and are instead combined in the results under the broader categories "aggressive" and "guarding" behaviour. Rates of aggression for "aggressive" and "guarding" behaviours were calculated as the frequency of aggressive acts divided by time spent away from the nest, or under the 
Table 1. Ethogram describing male reproductive behaviours used in analysis of video observations

\begin{tabular}{|c|c|c|}
\hline Behaviour & Description & Experiment \\
\hline $\begin{array}{l}\text { Contact } \\
\text { aggression: }\end{array}$ & $\begin{array}{l}\text { Male fathead minnow contacts and displaces } \\
\text { his opponent away from the nest. Includes } \\
\text { butting, biting, and tailbeating (see McMillan } \\
\text { and Smith 1974). }\end{array}$ & $1,2,3$ \\
\hline $\begin{array}{l}\text { Non-contact } \\
\text { aggression: }\end{array}$ & $\begin{array}{l}\text { Male fathead minnow displaces his opponent } \\
\text { without bodily contact. Includes chasing and } \\
\text { tailbeating without contact (see McMillan } \\
\text { and Smith 1974). }\end{array}$ & $1,2,3$ \\
\hline Aggressive: & $\begin{array}{l}\text { Includes contact and non-contact aggression, by } \\
\text { a non-nesting male. }\end{array}$ & $1,2,3$ \\
\hline Unaggressive: & $\begin{array}{l}\text { Non-nesting focal male avoids and/or does not } \\
\text { elicit aggressive encounters with his opponent. } \\
\text { Includes swimming the periphery of the } \\
\text { aquarium, hovering, or fleeing from threats } \\
\text { or attacks (see McMillan and Smith 1974). }\end{array}$ & $1,2,3$ \\
\hline Nesting: & $\begin{array}{l}\text { Focal male is positioned beneath the nest site. } \\
\text { Includes hovering, contact movements, } \\
\text { touching, circling, rubbing and nibbling } \\
\text { (see McMillan and Smith 1974). }\end{array}$ & $1,2,3$ \\
\hline Guarding: & $\begin{array}{l}\text { Includes contact and non-contact aggression } \\
\text { by a nesting male. }\end{array}$ & $1,2,3$ \\
\hline Usurped: & $\begin{array}{l}\text { Non-focal male displaces the nesting focal male } \\
\text { from the nest site and proceeds with nesting } \\
\text { behaviour. }\end{array}$ & 3 \\
\hline Takeover: & $\begin{array}{l}\text { Focal male displaces the nesting non-focal male } \\
\text { from the nest site and proceeds with nesting } \\
\text { behaviour. }\end{array}$ & 3 \\
\hline
\end{tabular}

nest, respectively (Table 1). Nest site acquisition is reported as the proportion of males in a given treatment group that performed "nesting" behaviour (Table 1) irrespective of frequency or duration.

\section{VTG Analysis}

Concentrations of the egg yolk precursor, vitellogenin (VTG), were determined in whole body homogenates using an indirect competitive ELISA assay. Ninety-six well microplates were pre-coated with reagent $3.5 \mu \mathrm{g} \mathrm{mL} \mathrm{mL}^{-1}$ VTG in $50 \mathrm{mM}$ carbonate buffer, $\mathrm{pH}=9.6$, followed by block- 
ing of the unbound sites in each plate with $5 \%$ normal goat serum in the same buffer. Fathead minnows were homogenized whole in buffer (10 $\mathrm{mM}$ sodium phosphate, $150 \mathrm{nM}$ sodium chloride, $0.05 \%$ Tween-20, 0.02\% sodium azide with $50 \mu \mathrm{L} \mathrm{mL}^{-1}$ protease cocktail (Sigma P-8340). This crude homogenate was then centrifuged at $10,000 \times \mathrm{g}$ and the supernatant was appropriately diluted in ELISA buffer $(10 \mathrm{mM}$ sodium phosphate, $150 \mathrm{mM}$ sodium chloride, $0.05 \%$ Tween-20) of $\mathrm{pH}$ 7.3. Samples, as well as standards, were incubated for $1 \mathrm{~h}$ at $37^{\circ} \mathrm{C}$ with a primary antibody (Vtg-03, Biosense Laboratories, Bergen, Norway). Samples and standards were dispensed by pipette into the appropriate pre-coated wells and incubated for $1 \mathrm{~h}$ at $37^{\circ} \mathrm{C}$. After washing the plate with ELISA buffer, a secondary antibody conjugated to horseradish peroxidase (Sigma product no. A0168) was added to the plate, and incubated for an hour at $37^{\circ} \mathrm{C}$. A two-part 3,3',5,5'-tetramethylbenzidine and $\mathrm{H}_{2} \mathrm{O}_{2}$ substrate (Kirkegaard and Perry Laboratories, Gaithersburg, Mass.) was added to each well to react with the peroxidase enzyme conjugated to the secondary antibody. The reaction was stopped after $5 \mathrm{~min}$ by the addition of $1 \mathrm{M}$ phosphoric acid and the yellow colour was read at $450 \mathrm{~nm}$ using a ELx 800 Universal Microplate Reader (Bio-Tek Instruments, Winooski, Vt.). Non-specific binding of the antibodies was quantified and corrected for in each plate.

Reagent VTG for coating the ELISA plates was obtained by exposing a laboratory stock of fathead minnows to waterborne EE2 $\left(15 \mu \mathrm{g} \mathrm{L}{ }^{-1}\right)$ for one week. Blood was drawn from the sinus venosus of anesthetized fish into heparinized (2 USP units of ammonium heparine per tube) microhematocrit capillary tubes. Whole blood was pooled into a 1.5-mL microcentrifuge tube retained on ice and centrifuged at $3000 \times \mathrm{g}$ to obtain plasma. Reagent VTG was purified from this plasma by the Molecular Biomarkers Core Facility, University of Florida, as described by Denslow et al. (1997) and stored at $-20^{\circ} \mathrm{C}$ until required.

\section{Statistical Analysis}

Nonparametric statistical tests were required for analysis of behavioural observations since transformation did not result in the data conforming to the assumptions of parametric statistics. Plasma VTG data was $\log$ transformed and homogeneity of variances was verified with a Levene's test. Differences in VTG concentration between treatments were assessed with a one-way ANOVA followed by a Tukey HSD multiple comparison test. Spearman's rank correlation test was used to examine the relationship between VTG concentrations and total nesting aggression or latency to nesting.

\section{Results and Discussion}

\section{Male Reproductive Behaviour}

Aggressive interactions between breeding male fathead minnows are closely linked to establishment and defense of territories (McMillan and 
Smith 1974). The objective of experiment 1 was to determine whether exposure to EE2 impairs a male's ability to acquire a nest site relative to unexposed males (Cvs.C, Cvs.L, and Cvs.H). Overall, control males showed significantly higher rates of aggressive behaviour (Table 1) than exposed males when data from Cvs.L and Cvs.H trial types were pooled $(T=36, p<0.05)$ (Fig. 1a). However, the rate of aggressive behaviour did not differ significantly between non-nesting control and treatment males in the Cvs.L $(T=9, p>0.05)$ and Cvs.H $(T=10, p>0.05)$ trial types. A significant difference in the rate of aggressive behaviour for treatment males was not observed between trial types (Cvs.L trials, $1.0 \pm 0.4 \mathrm{per} / \mathrm{min}$; Cvs.H trials, $0.7 \pm 0.2 \mathrm{per} / \mathrm{min}$ ) (Fig. 1a).

In experiment 1 , nest site acquisition was significantly higher for control males when paired with males from the high dose treatment $\left(X^{2}=6.9\right.$,
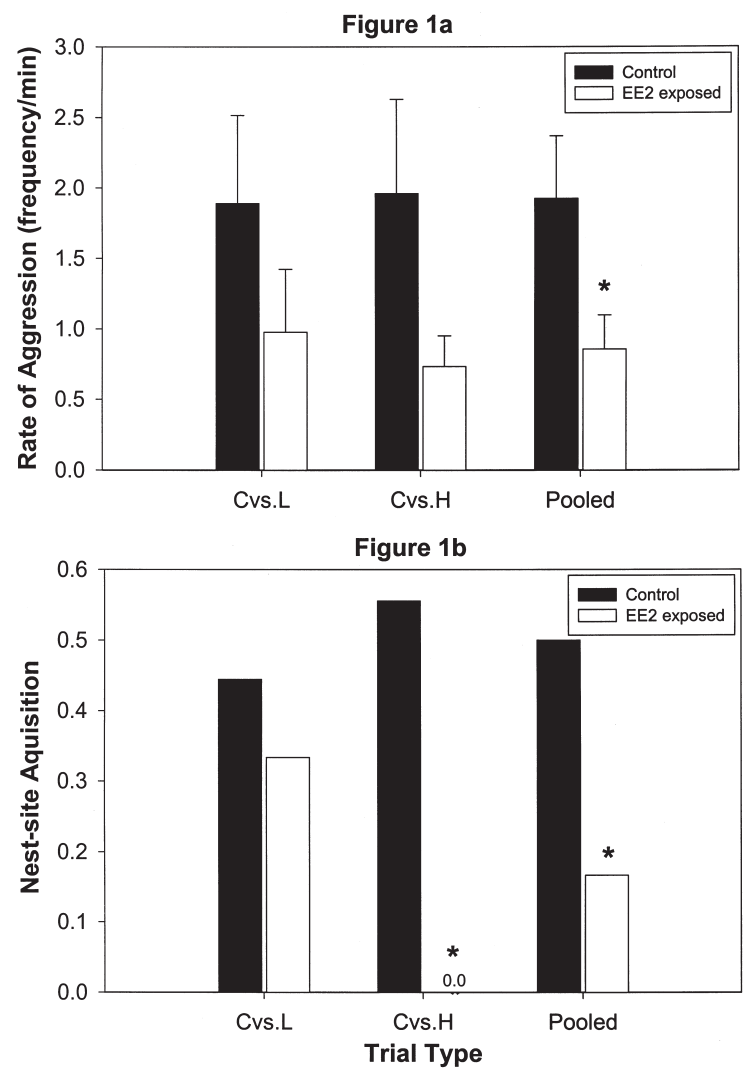

Fig. 1. A comparison of (a) the rates of aggressive behaviour (mean $+\mathrm{SE}$ ) and (b) the proportion of males that acquired nest sites in the control versus treatment trials of experiment 1 . Pooled bars represent a comparison of the rates of aggression $($ mean $+\mathrm{SE})$ of control versus treatment males when Cvs.L and Cvs.H trials were combined. ${ }^{*}$ indicates a significant difference from the control group at $\alpha=0.05$. 
$\mathrm{df}=1, p<0.05)$, with nesting behaviour being completely eliminated in high dose males (Fig. 1b). There was no significant difference in nest site acquisition between control males and low dose males $\left(X^{2}=0.23, \mathrm{df}=1\right.$, $p>0.05)$, suggesting that the low dose concentration $\left(2.0 \mathrm{ng} \mathrm{L}^{-1}\right)$ was not sufficient to produce a response. Experiment 3 examined a solitary male's ability to establish a territory, and to defend the nest site when paired with a male from the same treatment group. EE2 had no effect on the latency of nesting behaviour of focal males within trial types (Cvs.L, Cvs.H) $(U=8, p>0.05)$. Variability within and across the three treatment groups was high, with latency to nest ranging from 6 to $2394 \mathrm{sec}$. These results suggest that exposure to EE2 either does not effect the time it takes for a male to establish a nest site, or that the 40-min time limit for establishment of the territory was insufficient to discern an effect.

Experiment 3 also indicated that there was no significant difference in nest site acquisition by focal males across treatment groups (Cvs.C: $\mathrm{n}=11$, Lvs.L: $\mathrm{n}=9$, Hvs.H: $\mathrm{n}=8)\left(X^{2}=0.22, \mathrm{df}=2, p>0.05\right)$. It is possible that the presence of a sexually mature conspecific male or female may be necessary stimuli for territorial behaviour in fathead minnows, thus explaining the lack of effect in experiment 3. EE2 had no effect on the amount of time that focal males spent nesting across trial types in experiment $3(U=1.7, p>0.05)$. Results from experiments 1 and 3 suggest that exposure to EE2 results in reduced aggression and subsequently impairs a male fathead's ability to establish a nest site when paired with an unexposed male. Exposure to EE2 did not affect latency to nesting, or nest site acquisition, in the absence of another male.

Once a nest site has been established, reproductive success depends upon a male fathead's ability to defend its nest from potential egg predators and conspecifics that may attempt to overtake the nest. No significant difference was detected in the rate of guarding behaviour (Table 1) for focal males among trial types in experiment 3 (Cvs.C: $0.53 \pm 0.75$; Lvs.L: $0.10 \pm 0.14 ;$ Hvs.H: $2.11 \pm 4.21)(H=0.81, \mathrm{df}=2, p>0.05)$. High variability within the treatment groups in this experiment may indicate a need for larger sample sizes to accurately assess nesting aggression in male fathead minnows. These results indicate that exposure to EE2 at concentrations up to $8 \mathrm{ng} \mathrm{L}^{-1}$ does not affect the ability of a male fathead minnow to maintain a territory, when paired with like-treated conspecifics. Nest take-overs were present in Cvs.C and Hvs.H trials, however their occurrence was too infrequent for statistical analysis.

EE2 measurements in tank water that was extracted on C-18 solid phase extraction columns proved unreliable. Specifically, EE2 was detected in eluant from columns that had only ethanol and water drawn through them. In contrast, calculations of EE2 concentrations in the treatment tanks based on measurements of the stock solutions indicated that concentrations were near target $\left(\mathrm{C}=0.00 \mathrm{ng} \mathrm{L}^{-1}, \mathrm{~L}=2.04 \mathrm{ng}\right.$ $\left.\mathrm{L}^{-1}, \mathrm{H}=8.88 \mathrm{ng} \mathrm{L}^{-1}\right)$.

In order to compare overall levels of aggression among trial types, we summed the total rates of aggression (i.e., Guarding + Aggressive; Table 1) 
of paired males (i.e., Combined Total Aggression; Fig. 2) when in competition for a single nest site (experiment 1 ). Male fathead minnows were significantly more aggressive in the Cvs.L $(3.7 \pm 1.0)$ and Cvs.H $(2.9 \pm 0.6)$ trials than in the Cvs.C $(1.0 \pm 0.4)$ trials $(H=10.87, \mathrm{df}=2, p<0.05)$.

Because treatment males were generally less aggressive than control males (Fig. 1a), this result may be interpreted as a behavioural response of control males to the presence of a less aggressive conspecific. It is possible that a male fathead minnow varies the rate of aggression towards conspecifics based on the perceived risk of injury. During a spawning period, sexually mature male fathead minnows develop secondary sexual characteristics, such as raised tubercles on the head and pectoral fins, which are used during aggressive encounters. If secondary sexual characteristics are suppressed, as has been demonstrated during exposure to environmentally relevant concentrations of $17 \beta$-estradiol (MilesRichardson et al. 1999), it is plausible that the perceived risk of injury by conspecifics may be reduced.

Experiment 2 examined aggressive interactions between pairs of males from the same treatment group in competition for a single nest site. The rates of aggression for both males in a pair were combined and compared across all treatment groups. No difference in the combined total rates of aggression was detected across treatment groups (Cvs.C: $1.00 \pm 1.08$; Lvs.L: $0.06 \pm 0.05$; Hvs.H: $1.79 \pm 2.18)(H=1.35, \mathrm{df}=2, p>0.05)$. As discussed for experiment 1 , these results may reflect an ability to assess the relative risk of injury associated with an aggressive encounter. In this case, males across all treatments may perceive the risk of injury equally,

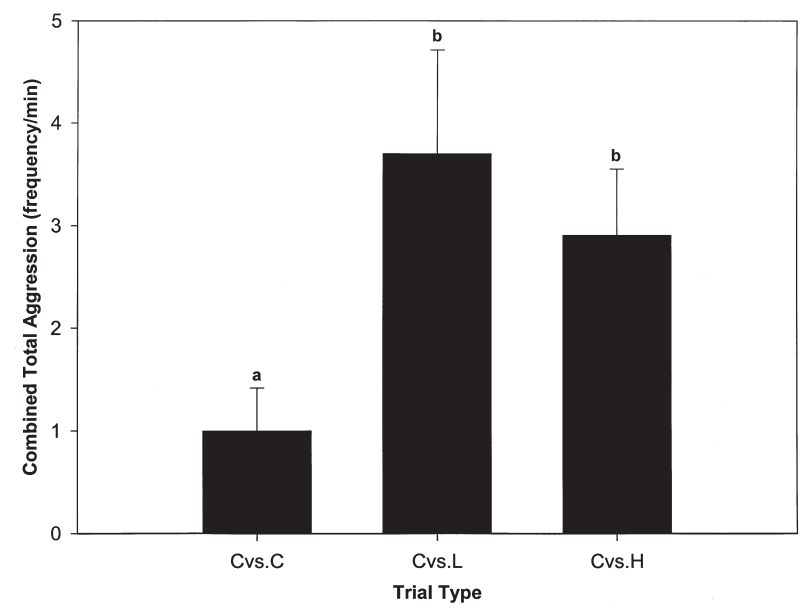

Fig. 2. A comparison of combined total aggression (i.e., sum of total rates of aggression for paired males) (mean $+\mathrm{SE}$ ) across trial types in experiment 1 . Bars with the letter (b) indicate a significant difference to bars with the letter (a) at $\alpha=0.05$. 
based on their relative levels of aggression and body condition. However, a more comprehensive understanding of fathead minnow reproductive behaviour is required before these results can be accurately interpreted.

\section{VTG Induction}

In experiment 3, VTG concentrations differed significantly among treatment types $(F=5724.12, \mathrm{df}=2, p<0.001)$. Fish from low and high dose treatments had significantly higher VTG levels $(\mathrm{L}=9016.9 \pm 689.6$ $\left.\mu \mathrm{g} \mathrm{g}^{-1} ; \mathrm{H}=10633.1 \pm 448.1 \mu \mathrm{g} \mathrm{g}^{-1}\right)$ than control fish $\left(2.6 \pm 0.1 \mu \mathrm{g} \mathrm{g}^{-1}\right)$ (Tukey HSD, $p<0.001$ ). No significant difference in VTG levels was observed between the low and high dose treatments. We found no correlation between VTG concentrations and the total rate of nesting aggression $(\rho=0.22, p>0.05)$ or latency to nesting $(\rho=0.38, p>0.05)$ in fish across all treatments in experiment 3 . The small sample size $(n=8)$, and the fact that a second male was only added to the observation tank after the initial male took ownership of the nest site, may have influenced the relationship between VTG concentrations and the behavioural endpoints of experiment 3. These results suggest that, while VTG is a sensitive biomarker for estrogenic activity in fish, high concentrations of the protein may not directly impair reproductive behaviour. Research by Kramer et al. (1998) also suggests that VTG production in male fathead minnows is not predictive of impaired reproductive traits, such as courtship and defensive behaviour. However, exposure to $17 \beta$-estradiol has been demonstrated to impair sperm development and cause gonadal degeneration in fathead minnows at concentrations sufficient to cause VTG induction and much lower than is required to cause significant changes to secondary sexual characteristics (MilesRichardson et al. 1999).

Few studies have focused on the impacts of endocrine disrupters on reproductive behaviour in fish. This may be partially due to the fact that hormonal control of sexual behaviour in fish is poorly understood. However, it is well established that sex steroids play a key role (Demski and Hornby 1982; Kyle and Peter 1982; Borg 1994; Arcand-Hoy and Benson 1999; Bayley et al. 1999). Impaired reproductive behaviour due to estrogen exposure has been detected in fish species other than fathead minnows. A study exposing male goldfish (Carassius auratus) to waterborne $\left(0,1\right.$, and $\left.10 \mu \mathrm{g} \mathrm{L}^{-1}\right)$ and diet ingested $\left(0,1,10\right.$, and $\left.100 \mu \mathrm{g} \mathrm{g}^{-1}\right) 17 \beta$ estradiol for 24 to 28 days resulted in severe effects on reproductive behaviour (Bjerselius et al. 2001). Male goldfish sexual activity was 3 to 4 times lower in the diet ingested group, and 12 to 18 times lower in the waterborne exposure group, relative to control groups (Bjerselius et al. 2001). Another study exposing guppies (Poecilia reticulata) to $17 \beta$-estradiol $\left(10 \mu \mathrm{g} \mathrm{L}^{-1}\right)$ and 4-tert-octylphenol $\left(150 \mu \mathrm{g} \mathrm{L}^{-1}\right)$ for 28 days resulted in a dramatic decrease in the rate and intensity of the male sexual display (Bayley et al. 1999). Estrogen-induced changes to behavioural patterns should not be ignored because impairment of the ability to perform appropriate 
reproductive behaviours may significantly reduce success in attaining suitable mates and fertilization of female gametes.

The results of this study indicate that exposure to environmentally relevant concentrations of EE2 decreases aggression in sexually mature male fathead minnows competing for territories with unexposed conspecifics (Fig. 1a). However, when males were paired with individuals from their own treatment group, similar rates of aggressive behaviour were observed among treatment types. These results may be ecologically relevant in systems where fathead minnows are exposed intermittently, or to fluctuating levels of EE2. One such scenario is a river system where fish migrate between local populations situated upstream and downstream of sewage treatment plant inputs. A study comparing VTG induction between fathead minnows that were exposed either continuously or intermittently to $17 \beta$-estradiol resulted in approximately equal plasma VTG concentrations (Panter et al. 2000). Plasma VTG concentrations remained high after a 21-d depuration period, suggesting that estrogens remain active in the body for extended periods after exposure (Panter et al. 2000).

Well-established biomarkers for assessing estrogenic activity in fish include induction of the cytochrome P450 dependent monooxygenase system (Solé et al. 2000), in vitro responses at the cellular or receptor level, and VTG production in male fish (Bayley et al. 1999). While these biomarkers are highly sensitive, and serve as accurate indicators of estrogenic activity in fish, their links to reproduction are often tenuous (Sumpter 1995; Bayley et al. 1999). Biomarkers that address the potential impacts of environmental estrogen exposure on the reproductive capabilities of fish include measures of gamete viability (Kime and Nash 1999), morphological and histological impacts to the gonads and secondary sexual characteristics (Miles-Richardson et al. 1999). This study demonstrates the potential of male fathead minnow reproductive behaviour as a biomarker for estrogenic activity at environmentally relevant concentrations.

\section{Conclusions}

Male fathead minnows exposed to environmentally relevant concentrations of EE2 appear to be less aggressive, and nest less frequently, when paired with control males in competition for a nest site. However, aggression did not differ significantly between the 2- and 8-ngL ${ }^{-1}$ treatment groups. Exposure to EE2 did not significantly impede a male fathead minnow's ability to maintain a territory, based on the amount of time spent nesting and frequency of aggression towards non-nesting conspecifics. Overall rates of aggression were higher in trials where control males were paired with treatment males, but did not differ significantly when fish were paired with individuals from their respective treatments. Induction of VTG was significantly higher in treatment males than in control males. However, a relationship between VTG concentrations and reproductive behaviour was not detected. A more thorough 
understanding of the behavioural ecology of fathead minnows is required to accurately interpret the significance of these results to natural populations.

\section{Acknowledgments}

Equipment and funding for this study was supplied by the Department of Fisheries and Oceans, Canada. Thanks to Lenore Vandenbyllaardt for the EE2 analysis of tank water and stock solutions. Thanks to Wayne Clarke for supplying the minnows used in this study. Thanks to Jodi Holm and Julieta Werner for help with the care of the fish.

\section{References}

Allen Y, Scott AP, Matthiessen P, Haworth S, Thain JE, Feist S. 1999. Survey of estrogenic activity in United Kingdom estuarine and coastal waters and its effects on gonadal development of the flounder Platichthys flesus. Environ. Toxicol. Chem. 18:1791-1800.

Arcand-Hoy LD, Benson WH. 1998. Fish reproduction: an ecologically relevant indicator of endocrine disruption. Environ. Toxicol. Chem. 17:49-57.

Bayley M, Nielson J, Baatrup E. 1999. Guppy sexual behaviour as an effect biomarker of estrogen mimics. Ecotoxicol. Environ. Safety 43:68-73.

Bjerselius R, Lundstedt-Enkel K, Olsén H, Mayer I, Dimberg K. 2001. Male goldfish reproductive behaviour and physiology are severely affected by exogenous exposure to 17 $\beta$-estradiol. Aquat. Toxicol. 53:139-152.

Borg B. 1994. Androgens in teleost fishes. Comp. Biochem. Physiol. 109:219-45.

Cole KS, Smith JF. 1987. Male courting behaviour in the fathead minnow, Pimephales promelas. Environ. Biol. Fishes. 18:235-239.

Demski LS, Hornby PJ. 1982. Hormonal control of fish reproductive behaviour: brain-gonadal steroid interactions. Can. J. Fish. Aquat. Sci. 39:36-47.

Denslow ND, Chow M, Chow MM, Bonomelli S, Folmar LC, Heppell SA, Sullivan CV. 1997. Development of biomarkers for environmental contaminants affecting fish, p. 73-86. In Rolland RM, Gilbertson M, Petersen RE (ed.), Chemically induced alterations in functional development and reproduction of fishes. SETAC, Pensacola, Fla., U.S.A.

Desbrow C, Routledge EJ, Brighty GC, Sumpter JP, Waldock M. 1998. Identification of estrogenic chemicals in STW effluent. 1. Chemical fractionation and in vitro biological screening. Environ. Sci. Technol. 32:1549-1558.

Folmar LC, Hemmer M, Hemmer R, Bowman C, Kroll K, Denslow ND. 2000. Comparative estrogenicity of estradiol, ethynylestradiol and diethylstilbestrol in an in vivo, male sheephead minnow (Cyprinodon variegatus), vitellogenin bioassay. Aquat. Toxicol. 49:77-88.

Harries JE, Sheahan D, Jobling S, Matthiessen P, Neall P, Routledge E, Rycroft R, Sumpter J, Taylor T. 1996. A survey of estrogenic activity in the United Kingdom inland waters. Environ. Toxicol. Chem. 15:1993-2002.

Harries JE, Sheahan DA, Jobling S, Matthiessen P, Neall P, Sumpter JP, Tylor T, Zaman N. 1997. Estrogenic activity in five United Kingdom rivers detected by measurement of vitellogenesis in caged male trout. Environ. Toxicol. Chem. 16:534-542.

Harries JE, Janbakhsh A, Jobling S, Matthiessen P, Sumpter J, Tyler C. 1999. 
Estrogenic potency of effluent from two sewage treatment works in the United Kingdom. Environ. Toxicol. Chem. 18:932-937.

Kime DE, Nash JP. 1999. Gamete viability as an indicator of reproductive endocrine disruption in fish. Sci. Total Environ. 233:123-129.

Korte JJ, Kahl MD, Jenson KM, Pasha MS, Parks LG, LeBlanc GA, Ankley GT. 2000. Fathead minnow vitellogenin: complementary DNA sequence and messenger RNA and protein expression after 17ß-estradiol treatment. Environ. Toxicol. Chem. 19:972-981.

Kramer VJ, Miles-Richardson S, Pierens SL, Giesy JP. 1998. Reproductive impairment and induction of alkaline-labile phosphate, a biomarker of estrogen exposure, in fathead minnows (Pimephales promelas) exposed to waterborne 17ß-estradiol. Aquat. Toxicol. 40:335-360.

Kuch H, Ballschmiter K. 2000. Determination of exogenous estrogens in effluents from sewage treatment plants at the ng/L-level. Fresenius J. Anal. Chem. 366:392-395.

Kyle AL, Peter RE. 1982. Effects of forebrain lesions on spawning behaviour in the male goldfish. Physiol. Behav. 28:1103-1109.

Larsson DGJ, Adolfsson-Erici M, Parkkonen J, Pettersson M, Berg A, Olsson PE, Förlin L. 1999. Ethinyloestradiol-an undesired fish contraceptive? Aquat. Toxicol. 45:91-97.

McMillan VE, Smith JF. 1974. Agonistic and reproductive behaviour of the fathead minnow (Pimephales promelas Rafinesque). Z. Tierpsychol. 34:25-58.

Miles-Richardson SR, Kramer VJ, Fitzgerald SD, Render JA, Yamini B, Barbee SJ, Giesy JP. 1999. Effects of waterborne exposure of $17 \beta$-estradiol on secondary sex characteristics and gonads of fathead minnows (Pimephales promelas). Aquat. Toxicol. 47:129-145.

Nichols MK, Miles-Richardson SR, Snyder EM, Giesy JP. 1999. Effects of exposure to municipal wastewater in situ on the reproductive physiology of the fathead minnow (Pimephales promelas). Environ. Toxicol. Chem. 18:2001-2012.

Palace VP, Evans RE, Wautier K, Baron CL, Werner J, Klaverkamp JF, Kidd KA, Dick TA. 2001. Altered distribution of lipid-soluble antioxidant vitamins in juvenile sturgeon exposed to waterborne ethynylestradiol. Environ. Toxicol. Chem. 20:2370-2376.

Panter GH, Thompson R, Sumpter J. 2000. Intermittent exposure of fish to estradiol. Environ. Sci. Technol. 34:2756-2760.

Richardson LR. 1937. Observations of the mating and spawning of Pimephales promelas (Raf.). Can. Field-Nat. 51:1-4.

Rodgers-Gray TP, Jobling S, Morris S, Kelly C, Kirby S, Janbakhsh A, Harries JE, Waldock MJ, Sumpter JP, Tyler CR. 2000. Long-term temporal changes in the estrogenic composition of treated sewage effluent and its biological effects on fish. Environ. Sci. Technol. 34:1521-1528.

Solé M, Porte C, Barceló D. 2000. Vitellogenin induction and other biochemical responses in carp, Cyprinus carpio, after experimental injection with $17 \alpha-$ ethynylestradiol. Arch. Environ. Contam. Toxicol. 38:494-500.

Sumpter JP. 1995. Feminized responses in fish to environmental estrogens. Toxicol. Lett. 82/83:737-742.

Ternes TA, Stumpf M, Mueller J, Haberer K, Wilken R-D, Servos M. 1999. Behaviour and occurrence of estrogens in municipal sewage treatment plants-I. Investigations in Germany, Canada and Brazil. Sci. Total Environ. 225:81-90.

Unger LM. 1983. Nest defense by deceit in the fathead minnow, Pimephales promelas. Behav. Ecol. Sociobiol. 13:125-130. 
Wynne-Edwards VC. 1932. The breeding habits of the black-headed minnow (Pimephales promelas Raf.). Trans. Am. Fish. Soc. 62:382-383.

Zillioux EJ, Johnson IC, Kiparissis Y, Metcalfe CD, Wheat JV, Ward SG, Lui H. 2001. The sheephead minnow as an in vivo model for endocrine disruption in marine teleosts: a partial life-cycle test with $17 \alpha$-ethynylestradiol. Environ. Toxicol. Chem. 20:1968-1978. 